УДК 94 (47)

СОЛОВЬЕВА Екатерина Александровна - кандидат исторических наук, доцент кафедры истории Ульяновского государственного педагогического университета им. И.Н. Ульянова (432000, Россия, 2. Ульяновск, пл. Ленина, 4/5; kejt_84@mail.ru)

КОБЗЕВА Татьяна Александровна - кандидат исторических наук, доцент; декан историко-филологического факультета Ульяновского государственного педагогического университета им. И.Н. Ульянова (432000, Россия, г. Ульяновск, пл. Ленина, 4/5; tadir@таil.ru)

\title{
СИСТЕМА ЗЕМСКОГО СТРАХОВАНИЯ В СРЕДНЕМ ПОВОЛЖЬЕ В КОНЦЕ ХІХ - НАЧАЛЕ XX в.
} (на материалах Симбирской губернии)

\begin{abstract}
Аннотация. Статья посвящена анализу деятельности земств в сфере противопожарного страхования. Частые пожары в стране способствовали популярности данного вида страхования. Большое влияние на становление земского страхования на рынке страховых услуг оказали буржуазные реформы 1860-х гг., способствовавшие увеличению числа страхователей. Процедура получения полиса включала в себя несколько этапов, а подробное делопроизводство при заключении страхового договора, четкий порядок действий при наступлении страхового случая, жесткие условия получения вознаграждения должны были исключить все возможные риски, которые покрывает страховой полис, и возможность незаконного получения прибыли страхователем. Несмотря на все эти меры, страховые общества могли отказать в страховании без объяснения причины.
\end{abstract}

Ключевые слова: страхование от огня, полисный договор, страховая премия, Симбирская губерния, земство

$\mathrm{B}$ озрождение рыночных отношений в России в начале 1990-х гг. затронуло все сферы жизни общества, включая и сферу страхования. На современном этапе в развитии страхового дела наблюдаются тенденции, которые были характерны для данной сферы в период 1861-1917 гг. Так, правовое регулирование страховой деятельности в новых экономических условиях заметно отстает от современных требований общества, хотя на страховом рынке России действуют тысячи компаний, которые в своих учредительных документах заявили о намерении оказывать страховые услуги. Отрицательно сказывается на развитии страхового рынка и отсутствие мер стимулирования населения и предприятий к более широкому использованию возможностей страхования для защиты своих имущественных интересов. Сходная проблема существовала и в конце XIX в., когда многие положения о взаимном земском страховании, морском страховании судов и грузов уже не отвечали реальным экономическим потребностям общества [Райлян 2005].

В статье ставится задача проанализировать процесс становления земского страхования, особенности делопроизводства и перечень страхуемого имущества, а также показать преимущества и недостатки данного вида страхования.

Земское страхование было «сконструировано» на государственном уровне с целью обеспечения крестьянских хозяйств защитой на случай пожаров, которые были весьма распространенным и разрушительным бедствием, от которого Симбирская губерния несла большие убытки (так, в 1864 г. в г. Симбирске произошел крупнейший пожар). Страхование представляло одну из крупных и сложных отраслей земского хозяйства. Постановка страхования в руках земств не вполне соответствовала уровню его государственной важности. Накопление 
страховых капиталов земствами дало им возможность шире развить превентивную деятельность [Кобзева 2015].

Государство устанавливало основные принципы осуществления того или иного вида страхования и выступало гарантом исполнения обязательств по страхованию теми страховщиками, которых оно уполномочило вести страховую деятельность на установленных им условиях.

Положение «О земском страховании» 1864 г. выделяет 3 вида страхования, осуществляемого губернскими земскими управами: окладное (обязательное), дополнительное и добровольное. При этом, если имущество крестьянина уже было застраховано в другом страховом учреждении, например в частном акционерном обществе, обязательное земское страхование можно было уже не осуществлять. Кроме того, по ходатайству губернского земского собрания министр внутренних дел мог давать разрешение на обязательное страхование некоторых построек, находящихся ближе 50 саженей от сельских домов [Краюшкина 2013: 20].

Обязательность страхования определялась в дореволюционной России не только по отношению к определенным объектам страхования или страхователям, но и по отношению к страховым организациям. Например, если в системе взаимного земского страхования страхователь страховал свое строение в размере оклада, то по его желанию ему обязаны были оформить дополнительное страхование того же имущества до его полной стоимости на условиях окладного страхования. Под окладом в данном случае подразумевается максимальная страховая сумма при обязательном страховании строения.

При окладном страховании объектами страхования выступали строения, принадлежащие крестьянам. Страхователи также могли застраховать их сверх окладных норм на тех же условиях в рамках дополнительного страхования.

Действовавшее законодательство предусматривало, что обязательному (окладному) страхованию подлежат все сельские постройки, как частные, так и общественные, находящиеся в «черте крестьянской оседлости». Обязательное и добровольное страхование строений осуществлялось в пределах особых норм, но не выше $75 \%$ стоимости строения. Кроме окладного, существовало дополнительное, сверхокладное страхование, позволяющее крестьянам страховать свои домовладения по полной стоимости. При этом земское страхование было ограниченным по территории, т.е. земства имели право страхования только на территории своей губернии. Взаимное земское страхование осуществлялось во всех 52 губерниях Российской империи и являлось, по сути, социальным страхованием [Муталиева, Дашко 2013: 54].

Первоначально нормативной базы для организации земского страхования не существовало. Были попытки разработать проект правил по добровольному земскому страхованию в 1898 г. ${ }^{1}$, однако он так и не был принят вплоть до составления специальной инструкции в 1910 г. Деятельность страхового отдела земства регулировалась циркулярами и постановлениями Симбирской губернской земской управы. До начала XX в. вопросы, какие строения подлежат или не подлежат обязательному и добровольному страхованию, решались исключительно циркулярно. Циркуляры и распоряжения по страховому делу получали волостные старшины, страховые агенты, сельские старосты и сборщики обязательного страхового сбора. Они отправляли подписку, рапорт с подписями в Симбирскую губернскую земскую управу о получении циркуляра, постановления, инструкции и их разъяснении ${ }^{2}$.

\footnotetext{
${ }^{1}$ Государственный архив Ульяновской области (ГАУО). Ф. 46. Оп. 1. Д. 155. Л. 5.

2 ГАУО. Ф. 46. ОП. 4. Д. 692. Л. 45.
} 
Так, в 1909 г. Симбирская губернская земская управа установила новый перечень недвижимого имущества, подлежащего обязательному страхованию. Согласно нему, за исключением сельских построек в черте крестьянской оседлости, обязательному страхованию не подлежали церкви, часовни, молитвенные дома, медресе, помещения без крыши, недостроенные и ветхие помещения ${ }^{1}$.

Максимальная сумма обязательного страхования не должна была превышать 600 руб., однако со временем она менялась в сторону увеличения. Общая сумма добровольного и окладного страхования должна была быть не выше $3 / 4$ действительной стоимости построек ${ }^{2}$.

В том же 1909 г. Симбирская губернская земская управа установила перечень недвижимого имущества, подлежащего дополнительному страхованию: это строения, подлежащие окладному страхованию; постройки разночинцев, расположенные в черте крестьянской оседлости; недостроенные строения и торгово-промышленные заведения, расположенные только во дворах или в ряду сплошных построек ${ }^{3}$.

Только в 1910 г. была издана единая для всей губернии Инструкция по страхованию обязательному в Симбирской губернии ${ }^{4}$. В ней прописывались задачи страхования; структура страхового управления; виды имущества, подлежащего обязательному и дополнительному страхованию; нормы и условия обязательного и дополнительного страхования; перечень должностей проводящих описание и оценку построек; порядок описания, оценки и переоценки построек; составление страховых списков; сбор страховых платежей; взыскание недоимок; порядок уплаты премий по страховым случаям; охрана страхового капитала; обязанности страхователя и порядок ликвидации убытков от пожара 5 .

Для волостных правлений и сельских старост в районах участковых страховых агентов отпечатывалась своя собственная инструкция, которая содержала в кратком виде положения из общей инструкции с некоторыми добавлениями, такими как окладное страхование частных построек, окладное страхование общественных построек, доставление агенту сведений, обязанности по пожарам ${ }^{6}$.

На полисе взаимного земского страхования Симбирской губернии были отпечатаны извлечения из правил добровольного страхования от огня, из которых следовало, что к добровольному страхованию принимались постройки Симбирской губернии, за исключением помещений оптовых и торговых складов, занятых легковоспламеняющимися веществами; фабрик и заводов, кроме перечисленных в тарифах (крахмальные, клееварные, гончарные, известеобжигательные, пиво- и медоваренные, мельницы водяные и т.д.); деревянные крытые деревом строения на маломерных местах и крытые соломой в городах; постройки огнедействующих заведений (дворы с такими заведениями страхуются на $20 \%$ дороже); строения без караульных в уездах ${ }^{7}$.

При обязательном страховании строение считалось «поступившим на страх» не с даты фактической оплаты страховой премии, как при добровольном страховании, а со срока первого страхового платежа. Таким образом, обязательное страхование, по сути, становилось (и почти всеми крестьянами воспринима-

\footnotetext{
1 Там же. Д. 180. Л. 4.

2 Там же. Л. 34.

3 Там же. Л. 11.

4 Там же. Л. 163.

5 Там же. Л. 164-178.

6 Там же. Л. 334-335.

7 ГАУО. Ф. 198. ОП. 1. Д. 844. Л. 6.
} 
лось) очередным видом налога. Уплата страховых взносов приурочивалась к времени уплаты остальных земских повинностей. Так, согласно ст. 378 Свода законов Российской империи, пошлины с застрахованного недвижимого и движимого имущества накладывались на страхователя при добровольном страховании. Они начислялись с 1000 руб. застрахованного имущества: 50 коп. в год или 4 1/6 в месяц; а с каждой сотни - по 5 коп. в год или 5/12 коп. в месяц 1 . Пошлины начислялись и взимались одновременно с совершением или возобновлением страхования. Сумма пошлины должна была быть указана на страховом полисе или заменяющем его документе. При этом если имущество было застраховано на несколько лет и с рассрочкой платежа страховой премии, то при уплате пошлины также применялась рассрочка 2 .

Невнесение премии не являлось причиной непредоставления страховой защиты, просто сумма долга записывалась как недоимки страхового общества. Это приводило, с одной стороны, к полному покрытию всех обязательных к страхованию объектов вне зависимости от фактической уплаты премий, с другой - к ухудшению финансового положения органов земского страхования. Недоимки были довольно существенными, в некоторые годы их размеры достигали более половины всех предполагавшихся сборов, что ухудшало ситуацию с выплатой пожарных вознаграждений [Карпенко 2015: 250].

Однако для крестьянства страхование было обременительно еще и потому, что трафик обязательного страхования предусматривал расходы на содержание страховых отделов земских управ [Васильев 1997: 123].

Наиболее широко было распространено взаимное земское страхование строений от огня, которое было введено в обязательной форме, но затем земствам было разрешено проводить и добровольное страхование, причем не только недвижимого, но и движимого имущества.

Срок страхования при добровольном земском страховании, как и при страховании в частных обществах, не был ограничен. Имущество можно было застраховать на срок менее года, на год или более года. Однако губернская управа имела право отказывать в страховании без объяснения причин. В подобном случае премия возвращалась владельцу.

В отличие от частного страхования, уполномоченные страхового отдела Симбирской городской земской управы имели право осуществлять осмотр застрахованных строений не только при первоначальном заключении договора о страховании, но и по желанию владельца, в случае возобновления страхования и через каждые 10 лет. При добровольном земском страховании владельцам страховых полисов разрешалось достраховывать постройки, но на следующих условиях:

1) страхователь теряет право на получение вознаграждения в земстве, если застраховал имущество выше действительной стоимости;

2) страхователь теряет право на получение вознаграждения в случае, если общая сумма превышает земскую оценку строений.

При смене владельца все права и обязанности по страхованию имущества переходили к новому владельцу.

Каждое земство имело список инспекторов, работающих с населением. Как правило, это были образованные люди, пользующиеся доверием населения. Список содержал информацию об уровне образования, годовом окладе, периодической прибавке, а также оплате разъездов инспектора 3 .

\footnotetext{
${ }^{1}$ Свод уставов о прямых налогах. - Свод законов Российской империи. T. V. Гл. 7. СПб: Русское книжное товарищество «Деятель». 1912. Доступ из справочно-правовой системы «КонсультантПлюс».

2 Там же.

3 ГАУО. Ф. 46. ОП. 4. Д.333. Л. 1.
} 
Процесс добровольного страхования начинался с подачи письменного заявления в отдел по делам страхования местного волостного правления (при этом к нему мог быть приложен план имущества с оценкой), если строение находилось в уезде и принадлежало к обычным домам и хозяйственным постройкам, или в уездную земскую управу, если строение находилось в городе или принадлежало к промышленным объектам ${ }^{1}$. Если оценка имущества не была произведена владельцем, то опись, оценку имущества, а также назначение страховой суммы и страховых платежей проводил инспектор в течение 14 дней со дня подачи заявления ${ }^{2}$. При этом, если оценивалось городское имущество, допускалось присутствие архитектора, а если промышленное предприятие - требовалось обязательное присутствие «добросовестных свидетелей из соседних дворов». Все мероприятия должны были быть проведены в 7-дневный срок ${ }^{3}$. Если страхуемое имущество находилось за городом, то все путевые издержки возлагались на страхователя ${ }^{4}$. Об уплате страховых премий высылалось уведомление в Симбирскую земскую управу с описанием суммы страховой премии, суммы за страховую доску (металлическая табличка, которая крепилась на фасадах застрахованных домов), почтовых расходов, пошлины в казну5.

После завершения процесса страхования владелец имущества получал полис, а в случае его утраты в течение 2 месяцев со дня подачи заявления о пропаже выдавался дубликат.

Земские страховые инспекторы, как и агенты частных страховых обществ, вели подробное делопроизводство. Дело о страховании включало в себя следующую информацию:

- план застрахованных строений (схема, дата создания, владелец, название местности) и опись строений: материал, назначение, высота стен, внутренняя отделка (штукатурка, краска и пр.);

- оценка строений (литеры строений по плану, название строений, количество кубических саженей, цена кубической сажени).

При этом осуществлялась раскладка страховой суммы на фундамент, стены, внутреннее устройство и крышу, а также учитывалась премия с каждой сотни рублей согласно табели. Однако даже при этом «на страх» принималось не выше $2 / 3$ действительной стоимости строения ${ }^{6}$.

Об истечении срока страхования имущества по полису страхователю высылалось извещение. Для продления нужно было оплатить указанную сумму и отправить об этом извещение в управу7.

Подписывая договор, страхователь брал на себя обязательства по соблюдению правил страхования. Владелец должен был сообщить в уездную или губернскую земскую управу об открытии в застрахованном здании технического или промышленного заведения (при этом, если заведение не подлежало страхованию, владелец лишался вознаграждения без возврата страховой премии); о ломке или пристройке; об изменении наличия жильцов, чьи занятия представляют опасность от огня; о дополнительном страховании; об изменении наличия легко возгорающихся веществ на складах. Правила устанавливали 3-дневный

\footnotetext{
1 Там же. Д. 69. Л. 80. «КонсультантПлюс».

3 Там же.

4 Там же.

5 ГАУО. Ф. 46. ОП. 1. Д. 74. Л. 4.

6 ГАУО. Ф. 46. ОП. 4. Д. 333. Л. 10-11.

7 ГАУО. Ф. 46. ОП. 1. Д. 69. Л. 34; ОП. 4, Д. 178. Л. 4.
}

2 Свод положений о взаимном страховании. - Свод законов Российской империи. Т. XII. Ч. 1. Гл. 1. От. 4. СПб: Русское книжное товарищество «Деятель». 1912. Доступ из справочно-правовой системы 
срок подачи заявления о наступлении страхового случая, иначе страхователь лишался вознаграждения (ст. 73 Положения о сроках в земском страховании). Страховая премия при этом не возвращалась. Задержка могла быть учтена только в случае непреодолимых обстоятельств, препятствующих такому оповещению1. При пожаре владелец не должен был касаться сгоревшего.

Страхователь ставил личную подпись, подтверждая, что он ознакомился с данными правилами. Под обязательством неграмотного подписывался представитель полиции, нотариус или мировой судья².

Государство обеспечивало финансовые гарантии исполнения текущих обязательств перед застрахованными лицами. При недостатке средств страхового капитала (т.е. капитала, формировавшегося за счет страховых взносов) для страховых выплат их разрешено было производить за счет других земских капиталов в пределах, разрешенных губернским земским собранием.

При наступлении страхового случая определение действительной стоимости строения в день пожара рассчитывалось следующим образом: из цены на материал и за работу в его новом виде (по существующим деньгам в день пожара) вычиталась цена за время использования, изношенность строения; полученная разность и была действительной стоимостью ${ }^{3}$. И страховая выплата не должна была превышать действительной стоимости имушества 4 .

По мере распространения и развития различных форм государственного страхования в Симбирской губернии возникал ряд проблем, требовавших немедленного решения.

15 мая 1908 г. Симбирская губернская земская управа направила циркуляр страховому отделу о существующих проблемах: это растрата денег волостными старшинами и ограбление касс волостного правления 5 . Причины этого были связаны с задержками волостными старшинами сдачи денег в казначейство. Для предотвращения подобных случаев страховые агенты должны были проводить ревизии делопроизводства своего участка каждый квартал вместо 1 раза в год; волостные старшины должны были сдавать деньги в казначейство при сумме свыше 500 руб., а сборщики - свыше 100 руб.

Обычными были дела о недоимках обязательного страхового сбора за сельскими обществами Симбирской губернии. Недоимки порой достигали $32 \%$ (около 1/3) приходящегося сбора ${ }^{6}$.

В период революции 1917 г. для страховых агентов губернского земства был разработан циркуляр от 30 октября 1917 г. ${ }^{7}$ В нем губернская управа просила с большой осторожностью принимать «на страх» усадьбы в связи с пожарами, возникающими на почве аграрного движения, сопровождавшимися разгромами и поджогами. Страховым агентам рекомендовалось составлять документы, но не принимать платежи, а направлять эти документы со своим заключением в губернскую управу, которая должна была сама выдавать разрешение на подобное страхование.

Таким образом, земское страхование давало большее поле для маневра, т.к. делилось на обязательное и добровольное. При этом не воспрещалось достраховывать имущество в частных страховых компаниях. В развитии земского сектора страхования можно отметить ряд преимуществ и недостатков такового

\footnotetext{
${ }^{1}$ ГАУО. Ф. 46. ОП. 1. Д. 74. Л. 5.

2 Там же. Д. 69. Л. 50.

3 Там же. Д. 155. Л. 6.

4 Там же. Л. 5.

5 Там же. Д. 180. Л. 65.

6 Там же. Д. 798. Л. 1.

7 Там же. Д. 790. Л. 3.
} 
для населения. Стоимость полиса при взаимном страховании по сравнению с договором коммерческого страхования была ниже, потому что из страхового тарифа исключена прибыль и отражены более приближенные к реальности расходы на ведение дела. Собранных средств должно хватать на покрытие убытков, но на первоначальном этапе это будет затруднительно из-за более низкой страховой премии. Целевое использование средств страховых резервов, а также возможность осуществления превентивных мероприятий за счет средств страхового фонда - одно из наиболее важных преимуществ земского страхования. Основными недостатками являлись его территориальная ограниченность, медленность организации и разработки инструкций по страхованию.

\title{
Список литературы
}

Васильев Г.В. 1997. История страхового дела в России. М.: Пресс-сервис. 251 с. Карпенко Т.А. 2015. Организация земского страхования в Самарской губернии. - Вестник молодых ученых Самарского государственного экономического университета. № 1(31). С. 248-254.

Кобзева Т.А. 2015. Обзор экономической деятельности земств в 1870-1890-е гг. (на материалах губерний Среднего Поволжья). - Власть. № 11. С. 197-201.

Краюшкина Е.И. 2013. Земское страхование в Тульской губернии 18641917 гг. - Вестник Московского городского педагогического университета. Сер. Исторические науки. № 2(12). С. 18-31.

Муталиева Л.С., Дашко В.М. 2013. Взаимное земское страхование в России во второй половине XIX - начале XX века как пример успешного социального противопожарного страхования. - Право. Безопасность. Чрезвычайные ситуаиии. № 3(20). С. 53-56.

Райлян А.И. 2005. Страховое законодательство Российской империи: 18611917 г2.: дис. ... К.ю.н. М. 219 с.

SOLOV'EVA Ekaterina Aleksandrovna, Cand.Sci. (Hist.), Associate Professor of the Chair of History, Ulyanovsk State Pedagogical University named after I.N. Ulyanov (4/5 Lenina Sq, Ulyanovsk, Russia, 432700; kejt_84@mail.ru) KOBZEVA Tatyana Aleksandrovna, Cand.Sci. (Hist.), Associate Professor; Dean of the Faculty of History and Philology, Ulyanovsk State Pedagogical University named after I.N. Ulyanov (4/5 Lenina Sq, Ulyanovsk, Russia, 432700; tadir@ mail.ru)

\section{THE SYSTEM OF ZEMSKY INSURANCE IN THE MIDDLE VOLGA REGION IN THE LATE 19TH - EARLY 20TH CENTURY (on the materials of Simbirsk Province)}

\begin{abstract}
The article is devoted to the analysis of zemstvo's activity in the field of fire insurance. The frequent fires in the country contributed to the popularity of this type of insurance. The bourgeois reforms of the $1860 \mathrm{~s}$, which contributed to the increase in the number of insurers, had a great influence on the formation of zemsky insurance in the insurance market. The procedure for obtaining the certificate of insurance included several stages. Detailed paperwork at the conclusion of the insurance policy, a clear procedure for the occurrence of an insured event, strict conditions for obtaining remuneration should exclude all possible risks that the insurance policy cover and the possibility of illegal profit by the insured. Despite all these measures, the insurance society could refuse insurance without giving a reason.
\end{abstract}

Keywords: fire insurance, policy agreement, insurance premium, Simbirsk province, zemstvo 